\title{
Fase Regional de Bragança das Olimpíadas de Química 2010
}

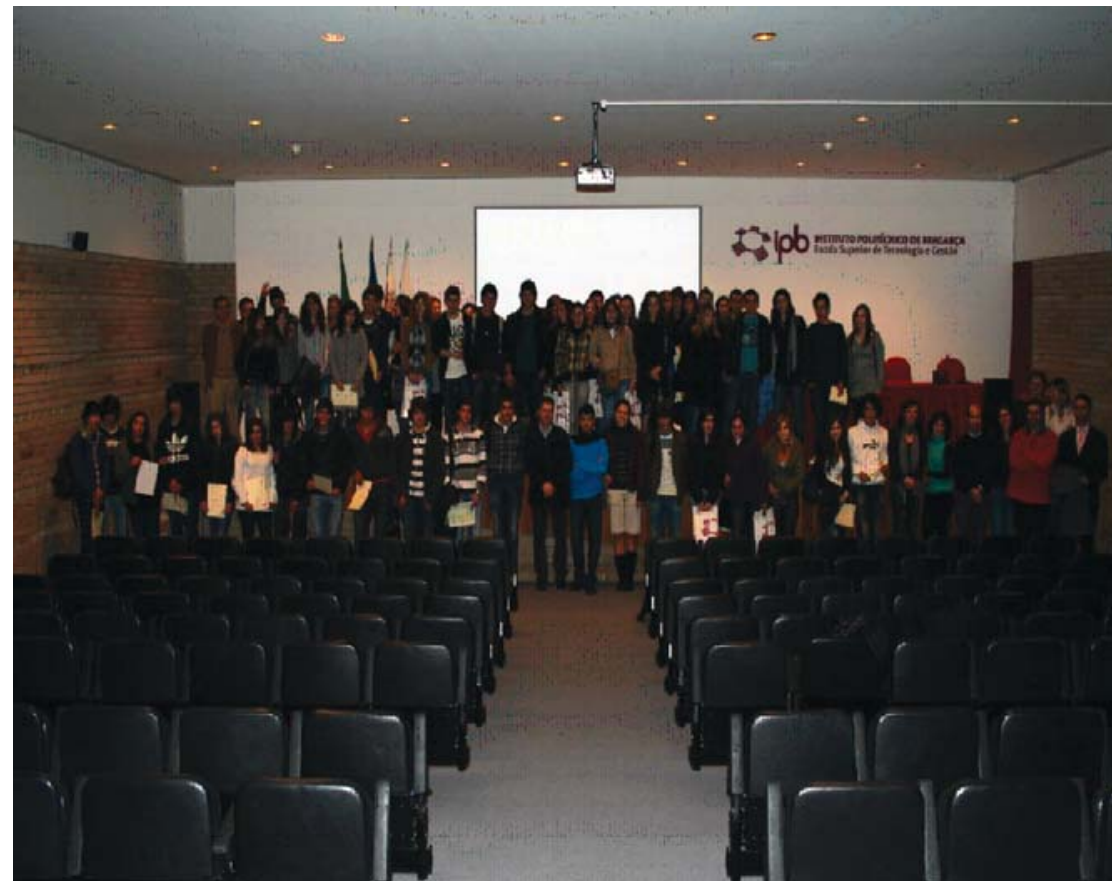

Alunos participantes e professores acompanhantes, presentes na Fase Regional de Bragança das Olimpíadas de Química+ 2010

Com o intuito de despertar o interesse pela Química e cativar os alunos para esta área científica, decorreu no dia 3 de Fevereiro, nas instalações da Escola Superior de Tecnologia e Gestão (ESTiG) do Instituto Politécnico de Bragança, a $5^{a}$ edição da Fase Regional de Bragança das Olimpíadas de Química+. A iniciativa, organizada pela Sociedade Portuguesa de Química (SPQ) em conjunto com o Departamento de Tecnologia Química e Biológica da ESTiG, contou com o apoio da Câmara Municipal de Bragança e do Crédito Agrícola.

A prova, destinada a alunos do $10^{\circ} \mathrm{e}$ $11^{\circ}$ anos do Ensino Secundário, foi elaborada com base nos conteúdos leccionados até ao $10^{\circ}$ ano e incluiu uma componente teórica e outra laboratorial.

Este ano participaram 5 escolas do Distrito de Bragança, nomeadamente a Escola EB2,3/S D. Afonso III de Vinhais, Escola EB2,3/S de Macedo de Cavaleiros e três escolas da cidade de Bragança: Escola ES/3 Abade de Baçal, Escola Secundária Miguel Torga e Escola ES/3 Emídio Garcia, perfazendo um total de 20 equipas, 59 alunos participantes e 9 professores acompanhantes.
Após a recepção dos participantes, as equipas foram distribuídas em 2 turnos, um dos quais iniciou a prova pela realização da componente teórica e o outro pela componente prática, trocando no final da realização de cada um dos tipos de prova.

Este ano, a prova prática laboratorial, realizada nos laboratórios de Processos Químicos e de Química Analítica, teve como objectivo a determinação do teor em ferro presente na água de um poço através de um método espectrofotométrico.

No final, todos os professores e alunos receberam um certificado de participação e lembranças diversas. Os alunos das 3 equipas mais bem classificadas receberam o prémio monetário "Crédito Agrícola" correspondente à abertura de uma conta na Caixa de Crédito Agrícola Mútuo no valor de $100 €, 75 €$ e $50 €$, para cada um dos alunos das equipas classificadas em $1^{\circ}, 2^{\circ}$ e $3^{\circ}$ lugares, respectivamente.

As equipas vencedoras foram as seguintes:

Equipa Classificada em $1^{\circ}$ lugar - Maria Inês Borges, João Pedro Bra-

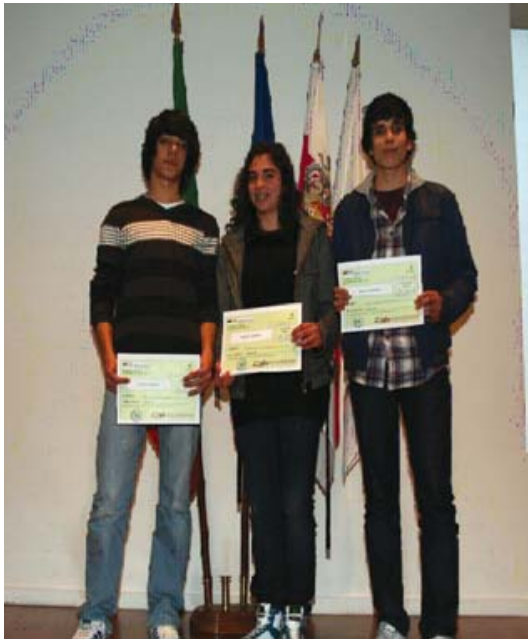

Equipa vencedora da Fase Regional de Bragança das Olimpíadas de Química+ 2010

gada e Ricardo Jorge Rodrigues (Escola ES/3 Emídio Garcia)

Equipa Classificada em $2^{\circ}$ lugar - José Francisco Amaro, Luís Paulo Rodrigues e João Pedro Rodrigues (Escola Secundária Miguel Torga)

Equipa Classificada em $3^{\circ}$ lugar - Ana Morais, Ana Fernandes e André Pires (Escola EB 2,3/S de Macedo de Cavaleiros)

Os $1^{\circ}, 2^{\circ}$ e $3^{\circ}$ lugares da classificação por escolas foram conseguidos pela Escola ES/3 Emídio Garcia, Escola Secundária Miguel Torga e Escola EB 2,3/S de Macedo de Cavaleiros, respectivamente. Todas elas foram premiadas com o financiamento da sua participação na Semifinal Nacional das Olimpíadas de Química+, que decorreram no dia 13 de Março no Porto (deslocação patrocinada pela Câmara Municipal de Bragança e alojamento patrocinado pelo Crédito Agrícola). $\mathrm{Na}$ Semifinal foram apurados os participantes na Final Nacional que se realiza no dia 8 de Maio de 2010 em Aveiro. Esta, por sua vez, permitirá apurar os alunos que representarão Portugal nas competições internacionais, nomeadamente nas Olimpíadas Internacionais e nas Olimpíadas de Química Ibero-Americanas. A estes e a todos os outros alunos, desejamos o maior dos sucessos pelos caminhos da Química!

Joana Amaral 